International Journal of Agriculture, Environment and Bioresearch

Vol. 4, No. 06; 2019

ISSN: $2456-8643$

\title{
DYNAMIC OF FISHING ACTIVITY ON THE SOLOMOUGOU DAM LAKE (KORHOGO, CÔTE D'IVOIRE)
}

\author{
Koffi Dongo Kouassi ${ }^{*}$, Moustapha Diaby ${ }^{2}$,Yao Nicolas Amon ${ }^{1}$ and Konan N'da ${ }^{3}$ \\ ${ }^{1}$ Peleforo GonCoulibalyUniversity, Department of Biological Sciences, BP 1428 Korhogo, Côte d'Ivoire \\ ${ }^{2}$ Peleforo GonCoulibalyUniversity, Agro-pastoral Management Institute, Korhogo, Côte d'Ivoire \\ ${ }^{3}$ Nangui-AbrogouaUniversity, Department of Nature Sciences, Abidjan, Côte d'Ivoire
}

http://doi.org/10.35410/IJAEB.2019.4481

\begin{abstract}
In northern Côte d'Ivoire, fishing is mainly practiced in agro-pastoral Dam Lakes. Previous studies on some of them indicated the possibility to increase their exploited production. This study was conducted from October 2018 to September 2019 on the Solomougou Dam Lake. Its objectives are to study the intensity of fishing activity and the rate of exploitation of this fishery. It appears that fishing is practiced throughout the year on this lake. However, $54.54 \%$ of fishermen stay there less than 6 months, also exploiting other fisheries in the region. Less frequented from August to October, its colonization gradually increases from November to reach the peak in March. Fishing gears are used seasonally. In fact, traps and gillnets are less used respectively during low water and flood periods of the Dam Lake. Sparrow hawks, less used by fishermen, are however used throughout the year while the use of longlines, bamboo traps and seine nets is limited to a few months. In terms of exploitation of the fishery, a density of 6.6 fishermen per $\mathrm{km} 2$ would be observed in a situation of full exploitation indicating a state of overexploitation of the fishery. However, taking into account fluctuations of fishermen's number per month, their densities ranged between 0.8 and 2.6 fishermen per km2 from July to December, indicative of normal exploitation of the fishery and between 3.2 and 4.2 fishermen per km2 outside this period, a little above the recommended standards.
\end{abstract}

Keywords: Variation; Fishing activity; Lake Solomougou; Côte d'Ivoire.

\section{INTRODUCTION}

In Côte d'Ivoire, fish is the main source of animal protein with an average consumption of 15 to $16 \mathrm{~kg}$ per year per inhabitant. Local production, mainly from the artisanal marine fishery, covers only $13.5 \%$ of the needs. As for inland fishery, it only provides a third of the artisanal fishery's catches (Failler et al., 2014).

In the north of the country, fishing is mainly practiced in agro-pastoral dams. These hydrosystems, built from the 1970s, are nowadays estimated at 210 (Le Guen, 2002). They provide large areas of water for crop irrigation and livestock watering to local populations (Cecchi et al., 2007). They are also now exploited for fishing, but they remain subject to fewer studies, perhaps because of the low levels of catches they generate. Da Costa et al. (2004) studies on some of these small reservoirs indicated the existence of a margin to increase their exploited production 
which varies between 70 and $250 \mathrm{~kg} / \mathrm{ha}$.year-1. Thus, better management of fishing activity on these reservoirs would certainly contribute to improving their yields.

In the department of Korhogo, there is Solomougou Dam, which is one of the five largest Dam Lakes in the north of the country (Traoré, 1996). Unfortunately, very little data is available on fishing there. So this study has been undertaken to seek to organize this activity. Its objectives are to study the intensity of fishing activity and the level of exploitation of this fishery during the year. The results will provide better understanding of fishing activity functioning.

\section{MATERIAL AND METHODS}

\subsection{Study area}

This study was conducted on Solomougou Dam Lake. It is located in northern Côte d'Ivoire, precisely in the department of Korhogo, 25 kilometers from this town on the road to Dikodougou. Its watershed is located between the meridians $5^{\circ} 30^{\prime}$ and $6^{\circ} \mathrm{W}$ and the parallels $9^{\circ}$ and $9^{\circ} 30^{\prime} \mathrm{N}$ (Anonyme, 1962). It was built in 1973 by Rice Development Society (SODERIZ). It covers a maximum area of 500 hectares of water (Traore, 1996).

\subsection{Data collection}

Fishing activity on Solomougou Damhas been followed from October 2018 to September 2019. Field samplings were conducted at the rate of two visits a week each month. They consisted of identifying fishermen present on the site during sampling period and of noting the arrival of new fishermen or the departure of those previously identified. Samplings also consisted of counting types of fishing gears used. A compilation of these monthly data allowed to highlight the fluctuations of fishermen's number on the site during the year and the periods of use of different fishing gears types. Also, water depth at the level of dam lakebed was noted at the beginning of each month with the objective to eventually establish relationship between the water level and the use of fishing gears types.

\section{RESULTS}

\subsection{Annual variations of water's depth}

Water's depths recorded at the level of dam lakebed are presented in Table 1. Period of low water is from February to June with depths ranging from 9 to 11meters. At the opposite, flood season starts from July to reach the peak of 39 meters in August. Then follows a gradual decrease in water level until low water period.

Table 1: Annual variations of water's depth from October 2018 to September 2019

\begin{tabular}{|lllllllllllll|}
\hline Month & O & N & D & J & F & M & A & M & J & J & A & S \\
\hline $\begin{array}{l}\text { Water } \\
\text { depth(meters) }\end{array}$ & 27 & 25 & 19 & 14 & 11 & 10 & 9 & 9 & 10 & 21 & 39 & 32 \\
\hline
\end{tabular}

\subsection{Length of stay of the fishermen on the site}


Analysis of Table 2 indicates that the length of stay of fishermen on the site varies between one (01) and twelve (12) months. Thus, two groups of fishermen are to be distinguished. These are, on the one hand, those staying for a short period on the site contrary to the second group.

Most of the fishermen stayed on the site for less than 6 months. In fact, $24.24 \%$ of them stayed there for only one month while $30.30 \%$ stayed there for four months.A second group of fishermen, fewer in number, stayed longer on the site for a period of 8 months for the majority of them. In any case, only two fishermen remained on the site for most of the year, 11 months for one and 12 months for the other.

Table 2: distribution of fishermen's stay in months on the site

\begin{tabular}{|lll|}
\hline $\begin{array}{l}\text { Length of stay of the } \\
\text { fishermen in months }\end{array}$ & Numbers & Frequencies (\%) \\
\hline 1 & 8 & 24.24 \\
2 & 0 & 0.00 \\
3 & 2 & 6.06 \\
4 & 10 & 30.30 \\
5 & 3 & 9.09 \\
6 & 0 & 0.00 \\
7 & 2 & 6.06 \\
8 & 5 & 15.15 \\
9 & 1 & 3.03 \\
10 & 0 & 0.00 \\
11 & 1 & 3.03 \\
12 & 1 & 3.03 \\
\hline
\end{tabular}

\subsection{Monthly variation of fishermen'snumber on Dam Lake}

A total of 46 fishermen were recorded during the study year. 26 of them were working as individual fishermen and 20 of them divided into 7 groups, members of each group using together the same fishing gear. In short, 33 fishing units exploited the dam during the year.

Analysis of Monthly variation of fishermen's number from October 2018 to September 2019 on the site (Figure 1) indicates that fishing is practiced throughout the year. However, the site remains less frequented from August to October with 4 to 7 fishing units or fishermen. From November, its colonization gradually increases to reach the peak in March with 21 units corresponding to 33 fishermen in total. Outside this period, the number of fishing units varies between 11 and 17 and the number of fishermen from 12 to 26 . 


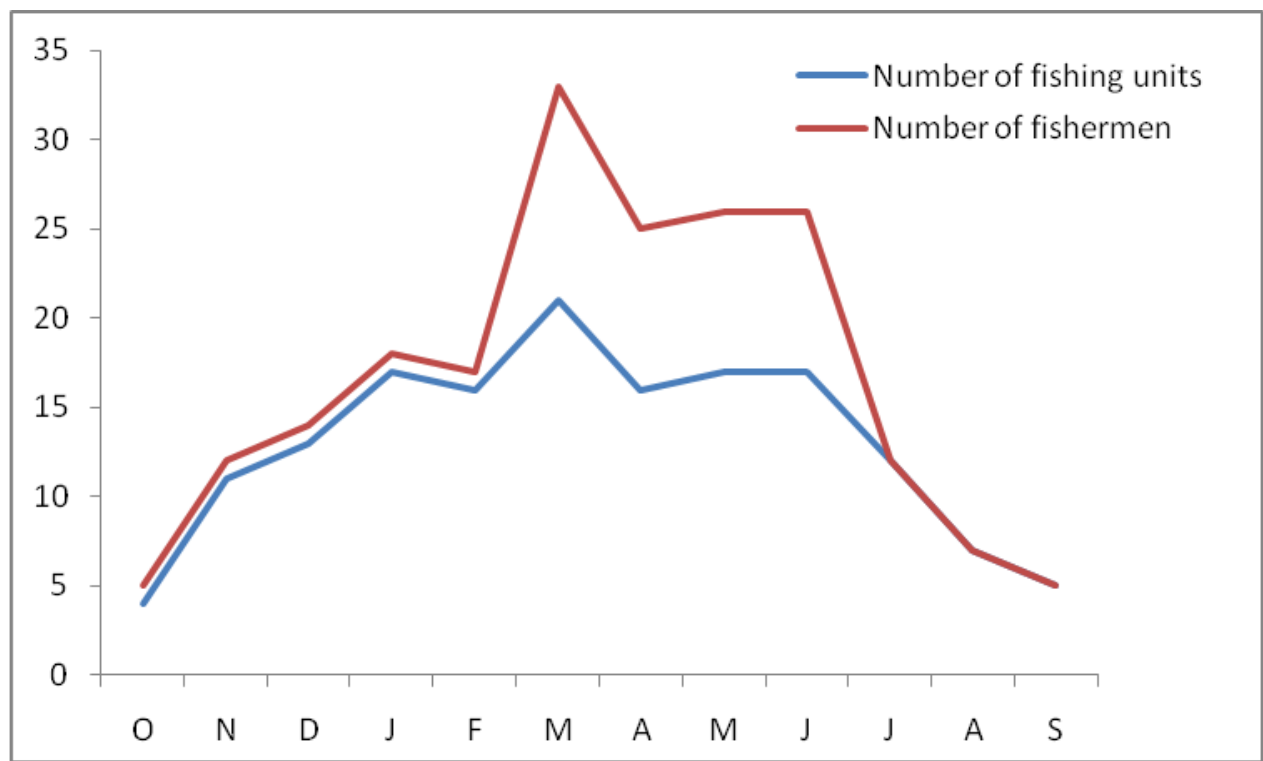

Figure 1: Monthly variation of fishermen's number from October 2018 to September 2019

\subsection{Period of use of fishing gears types}

\subsubsection{Traps}

Figure 2 shows that total number of traps used by fishermen per month varies from 20 to 130 . However, these fishing gears have been used by fishermen from July to March, but not from April to June in the period of low water. However, their heavy period of use is from October to February.

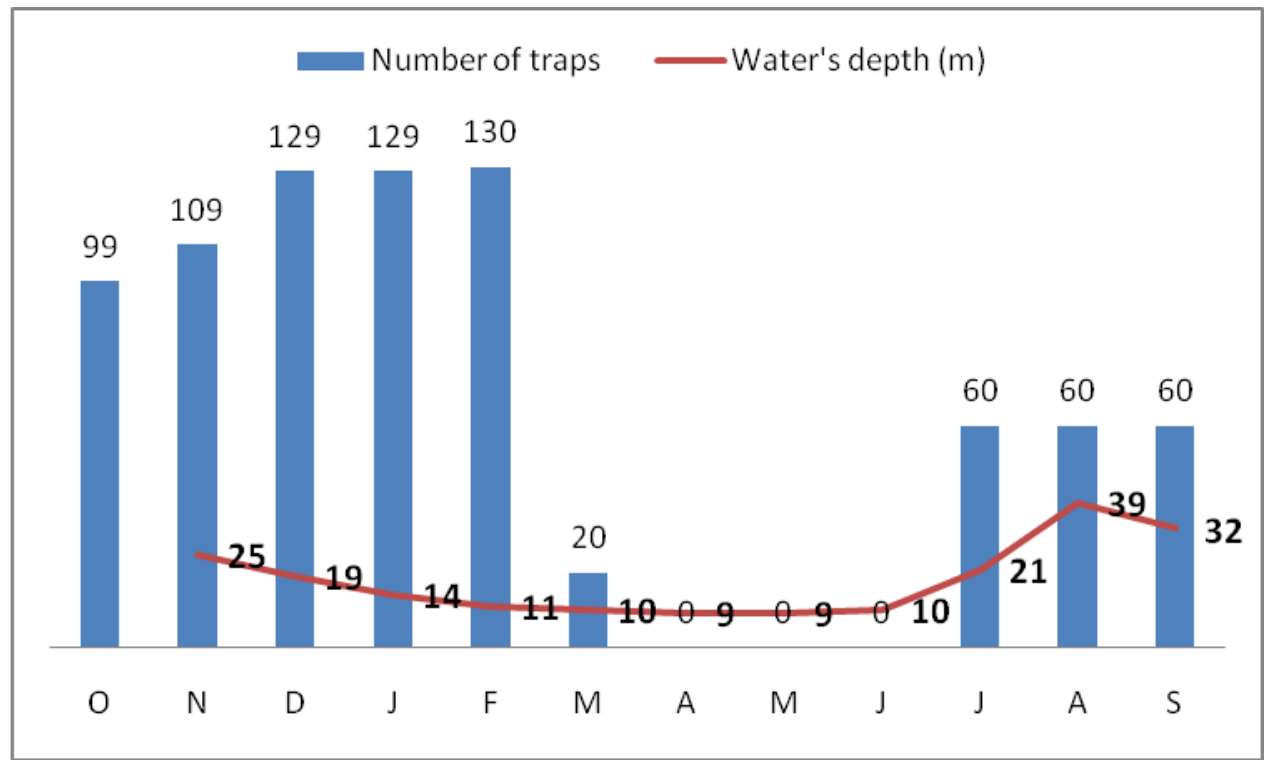

Figure 2: Monthly evolution of trap's numberon the site from October 2018 to September 2019

\subsubsection{Gillnets}


Figure 3 indicates that gillnet fishing has been practiced throughout the year regardless of the change in water depth, except in October. Total number of this fishing gear used per month varies from 4 to 71 . However, fishermen use them less from August to October ( 0 to 4 gillnets per month) in the flood period of the reservoir. The peak use of this fishing gear was recorded in March.

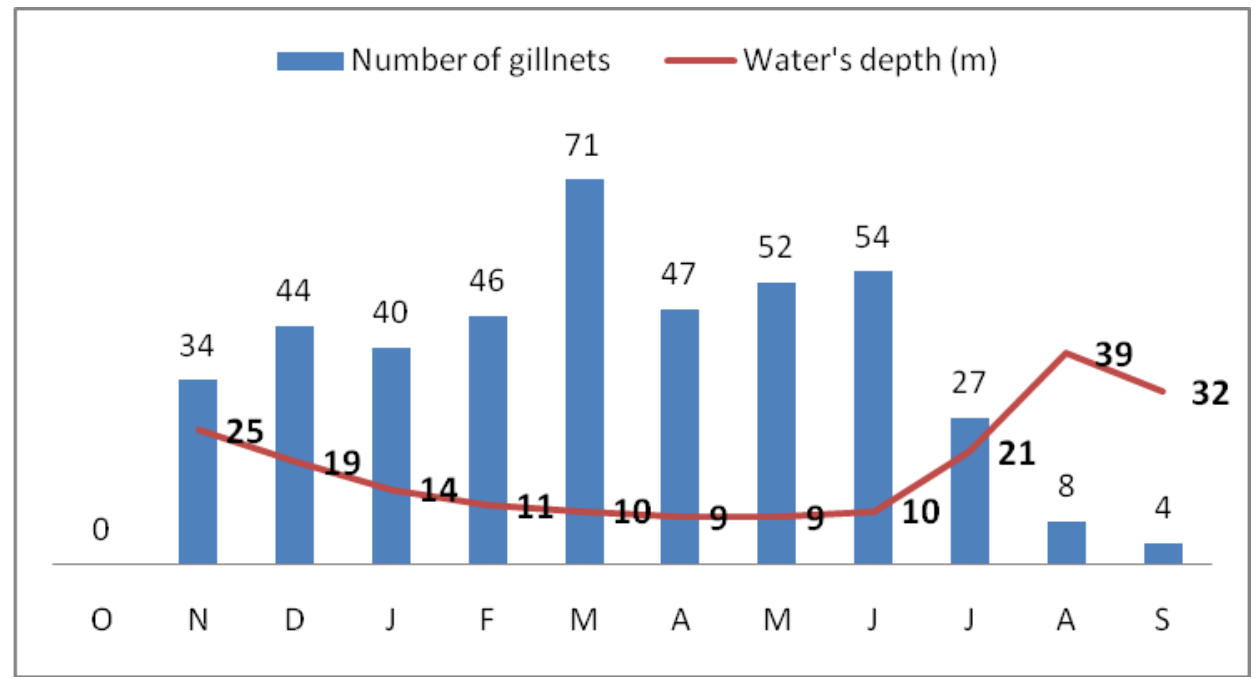

Figure 3: Monthly evolution of gillnet's number on the site from October 2018 to September 2019

\subsubsection{Sparrow hawks}

Figure 4 shows that sparrow hawksremained very poorly used by fishermen on the reservoir. Total number recorded per month varies from 1 to 6 . However, its use was extended throughout the year and during the half of the year, from April to September, by a single fisherman.

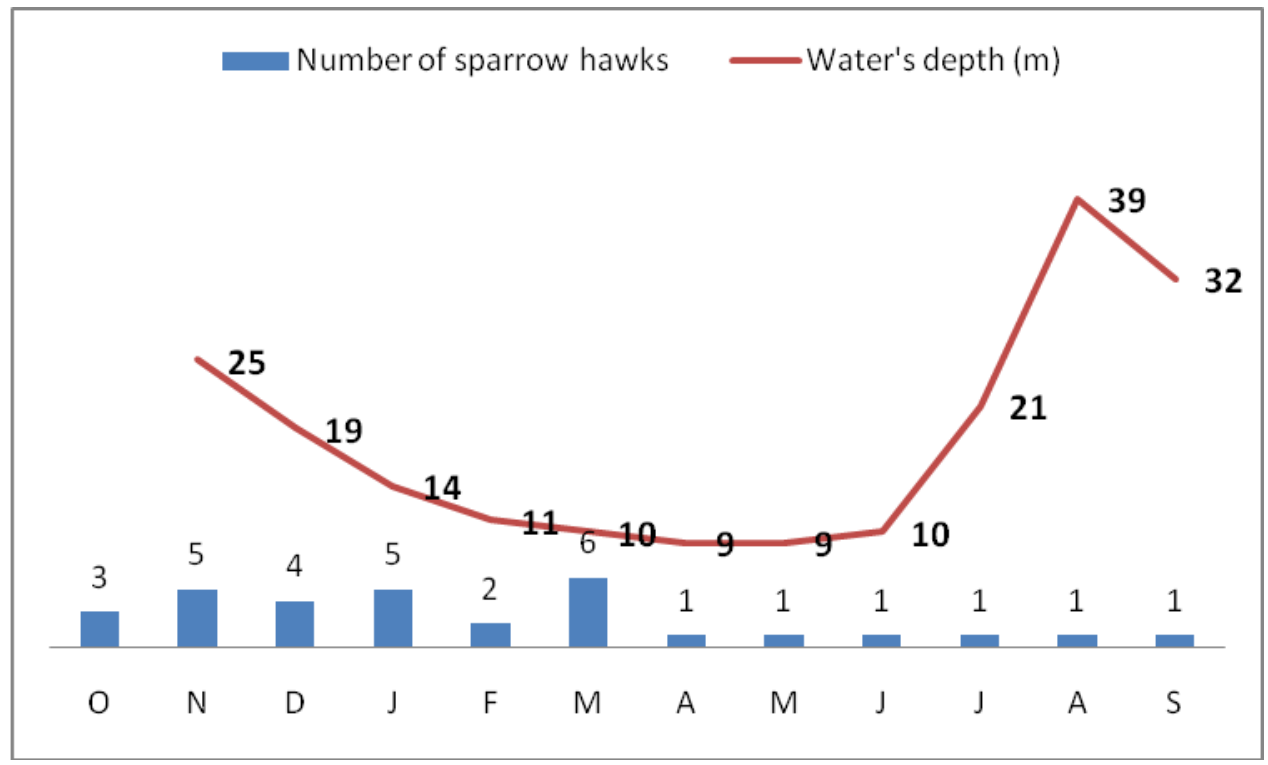


Figure 4: Monthly evolution of sparrow hawk's number on the site from October 2018 to September 2019

\subsubsection{Other fishing gears}

The other fishing gears such as longline, bamboo trap and seine net are characterized by their periods of use limited to a few months, as well as their low numbers per month. Indeed, longlineswere used during 7 months on the lake (Figure 5), 5 months for bamboo traps (Figure 6) and 4 months for seine nets (Figure 7). In addition, only 4 fishing units used seine nets and from March to June during low water period. As for longlines and bamboo traps, their periods of use were disparate and do not seem to be related to variations in water depth.

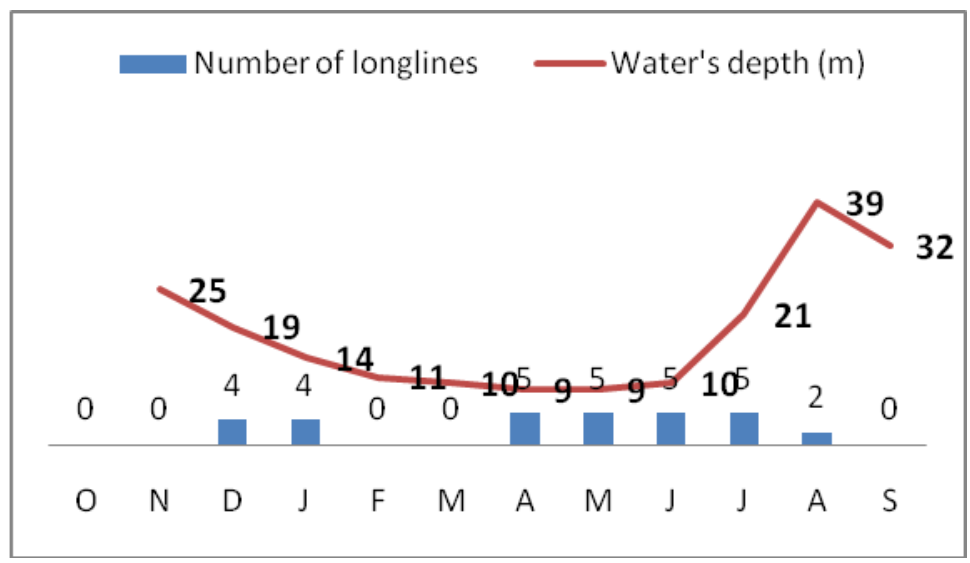

Figure 5: Monthly evolution of longline's number on the site from October 2018 to September 2019

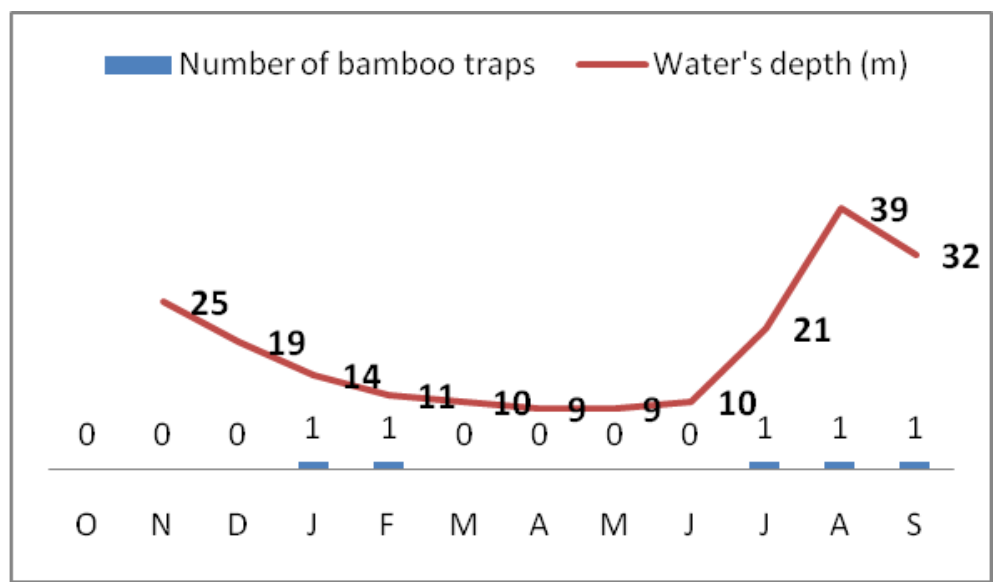

Figure 6: Monthly evolution of bamboo trap's number on the site from October 2018 to September 2019 
Vol. 4, No. 06; 2019

ISSN: $2456-8643$

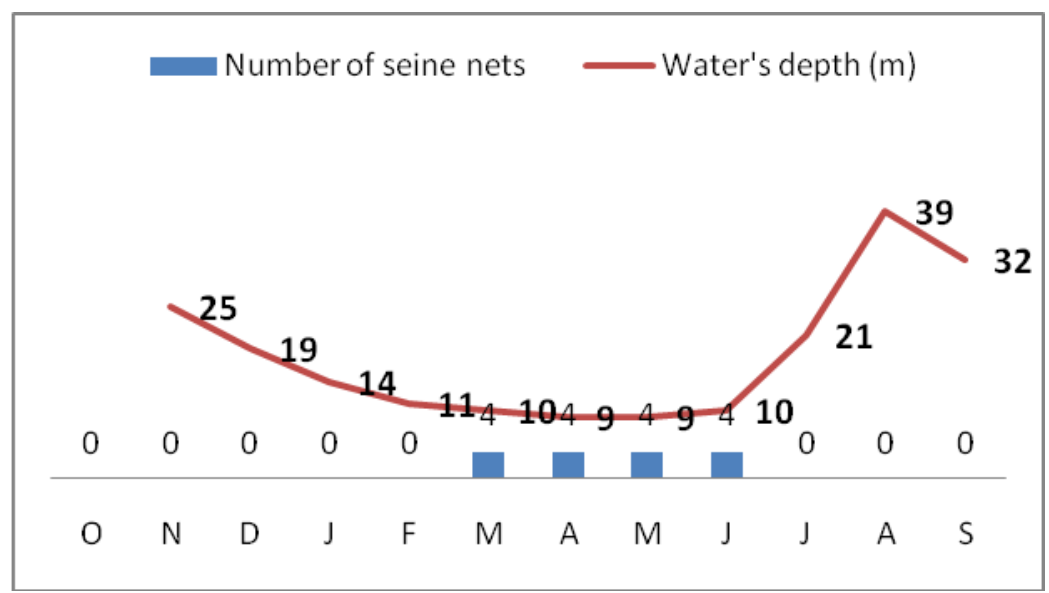

Figure 7: Monthly evolution of seine net's number on the site from October 2018 to September 2019

\subsection{Exploitation level of the fishery}

\subsubsection{In terms of number of fishing units}

The total number of fishing units recorded on the dam lake (500 hectares) during the study year is 33. This corresponds to a density of 6.6 fishermen per $\mathrm{km}^{2}$. However, the use of more than one fishing gear type by certain fishing units makes it possible to reconstruct the number of fishing units contained in Table 3. On this basis, fishermen using longline, bamboo trap and seine net are the least present at a density of less than one fisherman per $\mathrm{km}^{2}$ on the lake. The most numerous are those using gillnets at a density of 3.6 fishermen per $\mathrm{km}^{2}$.

Table 3: Number of fishermen per $\mathrm{km}^{2}$ according to fishing unit type

\begin{tabular}{|lllllll|}
\hline Fishinggears & Traps & $\begin{array}{l}\text { Sparrowhaw } \\
\text { ks }\end{array}$ & Gillnets & Longlines & $\begin{array}{l}\text { Bambootra } \\
\text { ps }\end{array}$ & $\begin{array}{l}\text { Seine } \\
\text { nets }\end{array}$ \\
\hline $\begin{array}{l}\text { Number of fishing } \\
\text { units reconstructed }\end{array}$ & 5 & 7 & 18 & 3 & 1 & 4 \\
$\begin{array}{l}\text { Number of fishermen } \\
\text { per } \mathrm{km}^{2}\end{array}$ & 1 & 1,4 & 3.6 & 0.6 & 0.2 & 0.8 \\
\hline
\end{tabular}

\subsubsection{In terms of number of fishing gears}

Table 4, expressing the number of fishing gears types per $\mathrm{km}^{2}$, shows that assuming optimal exploitation of the fishery, less than one bamboo trap and one seine net can be placed per $\mathrm{km}^{2}$ on the dam lake,against 1.8 and 2.2 respectively for longlines and sparrow hawks. It is rather gillnets and traps that are the most numerous with about thirty of each of them that can be arranged per $\mathrm{km}^{2}$. 
Vol. 4, No. 06; 2019

ISSN: $2456-8643$

Table 4: Number of fishing gears type per $\mathbf{k m}^{2}$

\begin{tabular}{|lccccccc|}
\hline Fishinggears & & Traps & $\begin{array}{l}\text { Sparrowhaw } \\
\text { ks }\end{array}$ & Gillnets & $\begin{array}{l}\text { Longline } \\
\text { s }\end{array}$ & $\begin{array}{l}\text { Bambootra } \\
\text { ps }\end{array}$ & $\begin{array}{l}\text { Seine } \\
\text { nets }\end{array}$ \\
\hline $\begin{array}{l}\text { Number of fishing } \\
\text { gears }\end{array}$ & 152 & 11 & 144 & 9 & 1 & 4 \\
$\begin{array}{l}\text { Number of fishing } \\
\text { gears per km }\end{array}$ & & 30.4 & 2.2 & 28.8 & 1.8 & 0.2 & 0.8 \\
\hline
\end{tabular}

\section{DISCUSSION}

Fishing is practiced on Solomougou Dam Lake throughout the year. However, the intensity of this activity shows two levels of variability. We notice, on the one hand, temporal variations of fishermen's number frequenting the lake and, on the other hand, length of their stay on the site.

Relative to temporal variations of fishermen's number, the site remains less frequented from August to Octoberin the flood period of the reservoir. From November, its colonization gradually increases to reach the peak in March during low water period.

As for length of stay of fishermen on the site, it varies between one and twelve months. This last observation allows to categorize fishermen into two groups. The former, with residence times less than eight months, belong to the category of nomadic fishermen. The latter, staying longer, are residents ones. This migration between different fisheries seems to be part of the habits of these fishermen of Malian origin. Togola (2009) reported an example of fishermen's migratory flow in Mali between Sélinguélake and the central delta in search of the best fishing areas. Let's remember that no less than 300 Dam Lakes are listed in northern Côte d'Ivoire. Five of them, called "big lakes" with an average surface area of 9,770ha are suitable for permanent exploitation for fishing. The other so-called "small lakes" have an average exploitable area of 1,500ha, where fishing is practiced periodically (Traore, 1996).

Concerning fishermen who have resided permanently for eight months on the lake, their departure from the site comes mainly during the rainy season. For them, when the dam is full, they do not have fishing gears adapted to floodwaters. As a result, fish become difficult to catch. So, they prefer to join their families in their native country for the practice of agricultural activities.

Finally, the small group of fishermen present on the lake during the twelve months is more constituted of Ivorians. They take advantage of the proximity of their locality around the dam to indulge in fishing throughout the year.

Six fishing gears are used by the fishermen on Solomougou Dam. They are trap, Sparrow hawk, gillnet, long line, bamboo trap and seine net. This study located periods of use of each of them. Three observations can be made at this level.

First, gillnets and sparrow hawks are the two fishing gears types used almost throughout the year. Then, seine nets remain exclusively used in dry season during low water period contrary to 
Vol. 4, No. 06; 2019

ISSN: $2456-8643$

traps not used during this period. Lastly, longlines are mostly used in medium and shallow waters, and not when water's level in the dam is maximum.

Seine nets fishing justifies its use when water's level is the lowest. In fact, the principle of this fishing method is to surround fish in a closed volume and then haul them on the ground. This cannot be done under high water. It's the same forlonglines, which are generally placed at the bottom looking for benthic species. Fishermen do not have adequate equipment to carry out this operation under high water.

On Solomougou Dam, 33 fishing units have been identified, exploiting 500 ha of the lake. This corresponds to a density of 6.6 fishermen per $\mathrm{km}^{2}$. Da Costa et al. (1988) reported that the recommended density for this type of fishery is 2 to 3 fishermen per $\mathrm{km}^{2}$. Thus, in a situation of exploitation of the fishery by all fishing units, Solomougou Dam would be in a state of overexploitation.

However, taking into account fluctuations of fishermen's number per month, their densities ranged between 0.8 and 2.6 fishermen per $\mathrm{km}^{2}$ from July to December. Thus, during six months in the year, densities remained below the optimal value of 3 fishermen per $\mathrm{km}^{2}$, indicative of normal exploitation of the fishery. Outside this period, the number of fishing units variedfrom 16 to 21 , corresponding to densities between 3.2 and 4.2 fishermen per $\mathrm{km}^{2}$, a little above the recommended standards.

\section{CONCLUSION}

On Solomougou Dam, fishing is practiced throughout the year by nomadic and sedentary fishermen. However, the site remains less frequented during flood period of the reservoir and most frequented during period of low water. Somme fishing gearsare used seasonally like seine nets, traps or longlines while gillnets and sparrow hawks are used almost throughout the year.Finally, in accordance with the density required for this type of fishery in terms of the number of fishermen per $\mathrm{km}^{2}$, SolomougouDam Lake is normally exploited from July to December and a little more overexploited outside this period.

\section{ACKNOWLEDGEMENTS}

Authors acknowledge administrative authorities in charge of the management of Animal and Halieutic Resources in the Department of Korhogo, who facilitated their relations with fishermen, as well as fishermen exercising on the Solomougou dam lake for their perfect collaboration.

\section{REFERENCES}

Anonyme, 1962. Étude hydrologique du solomougou. Résultats de la Campagne 1961. Document O.R.S.T.O.M., 79 p.

Cecchi P., Lévèque C. et Aubertin C., 2007.L'eau en partage : les petits barrages de Côte d'Ivoire. Paris, IRD, 295 p.

Da Costa K. S., Tito de Morais L. et Traoré K., 2004. Potentialités halieutiques des petits barrages du nord de la Côte d'Ivoire, Fiche technique, 7 p. 
Da costa K. S., Traoré K. et Tito de morais L., 1998.Effort de pêche et production exploitée dans les petites retenues du Nord de la Côte d'Ivoire. Bull. fran. Pêche. Piscic., 71 (348) : 65-78. Failler P., ElAyoubi H. et KonanA., 2014.Rapport $n^{\circ} 7$ de la revue de l'industrie des pêches et de l'aquaculture dans la zonede la COMHAFAT, $99 \mathrm{pp}$.

Le Guen T., 2002. Les barrages du Nord de la Côte-d'Ivoire : développement socio-économique et état sanitaire des populations. Brest, Université de Bretagne Occidentale, École doctorale des sciences de la mer, 2 volumes, (Doctorat nouveau régime en Géographie), 467 p.

Togola S., 2009.Les pêcheurs du lac de Sélingué, Hommes \& migrations, 1279, 24-37.

Traoré K., 1996. État des connaissances sur les pêcheries continentales ivoiriennes. Rapport de consultation Avril 1996, PROJET FAO TCP / IVC / 4553. 